\title{
Management of Learning Based on Pancasila Values in Early Childhood
}

\author{
Amstrong Harefa ${ }^{1 凶}$, Jesslyn Elisandra Harefa ${ }^{2}$, Maria Magdalena Zagoto ${ }^{3}$, Oskah Dakhi ${ }^{4}$ \\ Pendidikan Pancasila dan Kewarganegaraan, Universitas Nias, Indonesia(1); Ilmu Hukum, \\ Universitas Sumatera Utara, Indonesia(2); Pendidikan Matematika, Universitas Nias Raya, \\ Indonesia(3); Ilmu Komputer, Universitas Nias Raya, Indonesia(4) \\ DOI: $\underline{10.31004 / o b s e s i . v 6 i 4.2247}$
}

\begin{abstract}
The internalization of Pancasila is carried out from an early age. This is related to the problems in the community of the fading of the noble values of the Indonesian state's guidelines for life. The final goal of this study was to find the methods used by Teachers in instilling Pancasila values in early childhood in kindergarten. Qualitative research methods are used to achieve this goal by making kindergarten teachers as informants determined through purposive techniques and Snowball sampling. Data was collected by placing researchers as the primary "tool" supported by interviewing, observation, and documentation techniques. The netted data was analyzed with miles and Huberman's qualitative data analysis techniques. The results concluded that kindergarten teachers' level of knowledge and understanding about the types of learning methods in early childhood is quite good. Methods of planting Pancasila values used in some kindergartens in West Gunungsitoli Subdistrict include playing, telling stories, singing, conversing, demonstrations, role-playing, habituation methods, and tourism.
\end{abstract}

Keywords: learning management; pancasila values; early childhood

\begin{abstract}
Abstrak
Penanaman internalisasi Pancasila dilakukan sejak usia dini. Hal ini terkait permasalahan yang muncul pada masyarakat lunturnya nilai-nilai luhur pedoman hidup negara Indonesia tersebut. Tujuan penelitian ini adalah ditemukan metode-metode yang digunakan Guru dalam menanamkan nilai-nilai Pancasila pada Anak Usia Dini. Untuk mencapai tujuan tersebut digunakan metode penelitian kualitatif dengan menjadikan para guru Taman Kanak-Kanak sebagai informan yang ditentukan melalui teknik purposive dan Snow ball sampling. Data dijaring dengan menempatkan peneliti sebagai "alat" utama" didukung dengan teknik wawancara, observasi dan dokumentasi. Data yang terjaring dianalisis dengan teknik analisis data kualitatif model Miles dan Huberman. Hasil penelitian menyimpulkan bahwa tingkat pengetahuan dan pemahaman guru Taman Kanak tentang jenis-jenis metode pembelajaran pada anak usia dini cukup baik. Metode penanaman nilai-nilai Pancasila yang digunakan pada beberapa Taman Kanak-Kanak di Kecamatan Gunungsitoli Barat meliputi: metode bermain, bercerita, bernyanyi, bercakap-cakap, demonstrasi, bermain peran, metode pembiasaan, dan karyawisata.
\end{abstract}

Kata Kunci: pengelolaan pembelajaran; nilai-nilai pancasila; anak usia dini.

Copyright (c) 2022 Amstrong Harefa, et al.

$\triangle$ Corresponding author:

Email Address : amstrongharefa12@gmail.com \{Nias, Indonesia)

Received 5 November 2021, Accepted 5 February 2022, Published 16 February 2022 


\section{INTRODUCTION}

Early childhood is the best time to get an education. At this time, the child is undergoing a process of extraordinary growth and development. Children do not have many negative influences from outside of their environment. In other words, parents and educators will more easily direct children to be better. Early childhood is a very bright time to do and receive an education. Early childhood is the generation that will move on with life in the future. Early childhood is an asset of human resources that will bring progress and benefit to the life of the nation and state. Early age is when children can develop all their potential because, at this time, the child's development is faster than after passing an early age. The development of children at an early age will affect development at a later age (Khaironi, 2017).

Early childhood, between 0-8 years old, is a golden age, so they are very appropriate if used as an early community of nation character formation (Suryatni, 2017). Many experts refer to this period as the golden age that is the golden time owned by a child or when the child has a vast potential to develop. Experts conclude that success will determine the future of the child itself. The implication is that this success will undoubtedly impact the nation's future (Ariani, 2019; Sukmalia et al., 2021).

Early childhood is in dire need of guidance from others, especially parents. Parents are the most important to guide children. For this reason, parents in guiding their children must pay attention to their children (Jamiatul et al., 2020; Ruslan, 2020). Guidance from parents is very influential on children. Guidance from parents will be pervasive and embedded more deeply in early childhood is the right time to instill the values of Pancasila (Ariani, 2019; Lancaster, 2001; Lingkungan et al., 2021; Muliana et al., 2017). Early childhood usually tends to act according to its wishes regardless of its consequences. In addition, early childhood has a high curiosity, so they often ask questions that sometimes make people upset. At times like this, parents must answer patiently and based on Pancasila values to answer the question. Every behavior and deed also need guidance so that, little by little, his behavior is by the values of Pancasila (Bakhtiyar, 2019; Muliana et al., 2017).

Early childhood education is indeed essential, considering the goals that have been stated above. Instilling Pancasila values is also taught in schools. Educators can instill Pancasila values in their students in a fun way so that children feel happy even though they have indirectly embedded Pancasila values in children. Because the Indonesian state is based on Pancasila, education should prepare students to accept Pancasila and make Pancasila the basis of their lives (Angraini et al., 2019). For this reason, education in schools must be aimed at students to achieve the following awareness: (1). Trust and piety to God Almighty; (2). Manners and humane attitudes; (3). Love for the nation and the homeland; (4). Cultivate a democratic spirit; and (5). A sense of justice, honesty, truth, and helping others

Being the basis of an educator's thinking is also a parent when seeing a moral decline in the children environment. Various forms of morally deviant behaviour that exist in society will impact the perpetrators and people's lives in general. In the classroom context, there are also several moral issues: physical harm, psychological harm, and Justice or propriety. (Hildebrandt \& Zan, 2015; Dhiu \& Laksana, 2021; Zagoto \& Dakhi, 2018). Physical hazards contain violence in the form of hitting, pushing, pinching, etc. Psychological danger can be in the form of bullying behaviour, namely mocking, teasing, insulting, etc., and finally, Justice or decency in the form of destroying other people's goods, stealing, etc. Based on the social problems revealed above, there is a tendency that the education and teaching system developed in school institutions has not been successful, especially the teacher's lack of clarity in applying the concept of moral values. These methods are less effective in moral learning and tiny implementation in everyday life (Pratama \& Dewi, 2021; Sriwahyuni et al., 2017; Sulastri, 2021; Suryadi, 2015; Yenni, 2017).

Moral formation in children from an early age is also essential needed. It is intended so that the child's behaviour does not deviate from the values of Pancasila. Moral formation needs to be done little by little. By doing it, little by little, the child can understand and absorb 
it, which can then be applied in behaviour and actions. Instilling Pancasila values in early childhood can be done in various ways. It can be started from small things that are easy to catch, understand and do by the child. It is intended so that even children can, and it is easy to do it. Thus, children feel comfortable and happy to do it without feeling burdened (Fitriyani et al., 2021; Rusdiyani, 2015; Yenni, 2017). The problem is certainly not the responsibility of one party or alone in finding a solution. How big and important a process of coaching and synergizing between older people, schools, communities, and governments to continue to strive for personal changes in the process of meaningful education. The process of education is a demand of acquiring knowledge to be an intelligent person and have a noble character personality. Especially with the development of information technology in the millennial era, of early generation needs to be prepared a strong foundation related to ideology, especially guided by Pancasila and the 1945 Constitution (Febriyanti \& Dewi, 2021; Harefa, 2019).

The greatest hope that ideology is embedded in the behavior of everyday life will strengthen the character of the individual self, like the research conducted by (Amu \& Tampi, 2021; Harefa, 2021; Zagoto et al., 2019) to build a character of the nation's soul to build a village in Serang regency where the support of all levels of society will get maximum results to have good habituation behavior and moral. This village arises because of the rampant problems that occur will slowly forget about the identity owned by the nation. Of course, started to worry about the younger generation called the millennial generation. The biggest challenge for millennial youth is the spread of hoax issues involving a tribe, religion, race, and certain parts that cause division among the community.

Millennials have a role because they know technology and are still emotionally and psychologically fragile to be still affected. That negative influence will slowly undermine the noble cultural values that the Indonesian state already has as a characteristic of world civilization as a Godly Country that still views the whole human being, strengthens the soul of unity, has democracy in every problem for consensus and how high justice is viewed according to its level. It is expected that awareness of the importance of fortifying the nation's generation with 5 Precepts in Pancasila as a shield or a sturdy fortress to minimize the influence is not good (Febriyanti \& Dewi, 2021; Gunadi, 2013)

Moral formation in children from an early age is also needed. This is intended so that children's behavior does not deviate from the values of Pancasila (Kusumawati \& Zuchdi, 2019). Moral formation needs to be done little by little. By doing little by little, the child can understand and permeate it, which can then be applied in his behavior and actions. So that instilling the values of Pancasila in early childhood can be done in various ways. This method can be started from small things that are easy to catch, understand and do by the child. This is so that children can and quickly do this. Thjuuus, the child feels comfortable and happy without feeling burdened.

\section{METHODOLOGY}

This research uses a naturalistic qualitative approach. This research was conducted at an Early Childhood School in West Gunungsitoli District. The research population consisted of 12 teachers who taught at six early childhood schools. This research activity lasted for two months, namely in March and April 2021. Data was collected by placing researchers as the primary "tool" supported by interviewing, observation, and documentation techniques. Before being used, the interview guide instrument was validated by three validators, namely Dr. F. Lase, M.Pd, Kons., Ms. Elise M. M.Pd., and Ms. Nur H. M.Pd. The average validation results from the three validators is 85,98 show that they are in the very good category. The data sources in this study are teachers of West Gunungsitoli Subdistrict Kindergarten, which is determined by the integrated Purposive Sampling technique with snowball sampling. Data collection is done through interviews, observations, and documentation. Furthermore, data is analyzed with interactive techniques from Miles and Huberman through data collection procedures, data exposure, data reduction, and verification/conclusion. 


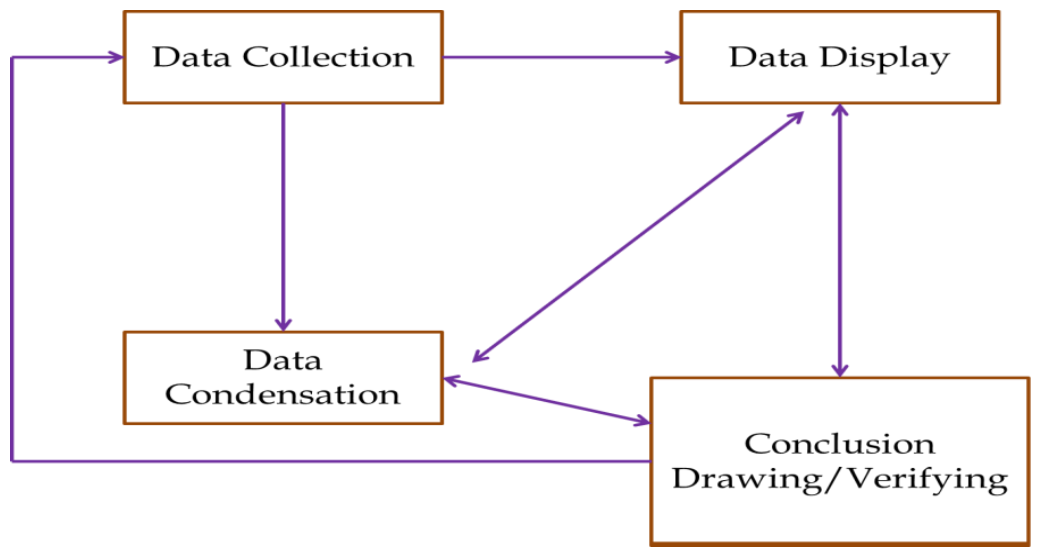

Figure 1. Miles and Hubermans Qualitative Data Analysis Flow

\section{RESULTS AND DISCUSSIONS}

\section{Teacher's Understanding of The Types of Learning Methods in Early Childhood}

Related to the teacher's understanding of the types of learning methods in early childhood, according to the first Informant as a teacher in Anugrah Kindergarten, knowledge of methods is our primary task as teachers, especially in choosing the method that best suits the characteristics of children in Kindergarten. The second Informant revealed the same thing as a teacher at Nifaeri Kindergarten, that of course, as kindergarten teachers, must understand what our duties as teachers include mastering learning methods. Briefly, the second Informant revealed that the learning method is used in the learning process to achieve the goals we have set in the Daily Learning Implementation Plan. This is also supported and in line with the statement of the next Informant, namely teachers of Samadaya Kindergarten and Paud Umbu.

Amu \& Tampi (2021) said besides the method written in the RPPH and also implicitly readable on the components and steps of learning, namely on the opening step, core activities, and closing activities. While two other informants, namely kindergarten teacher Anugrah Sendoro and Private Kindergarten Christian Epiphania, stated that initially, he became a teacher in kindergarten still did not understand the components of learning, including mastery of learning methods because he was not a bachelor of education but tried to find out through various reading sources and asked many other kindergarten teacher friends at each meeting through teacher working group activities kindergarten Western Gunungsitoli. Based on the interviews, all informants have participated in training that improves the quality of learning carried out by the Regional Government, Nias regional, LPM, and P4TK.

\section{Methods Used by Teachers In Instilling Pancasila Values in Early Childhood?}

Related to the methods used in instilling Pancasila values in early childhood, all informants conveyed that in the learning process, they use varied methods, while showing documents of the Daily Learning Implementation Plan with the theme of Plants and vegetable plant sub-themes, they set an example on the opening activities that were preceded by singing children's songs, praying before the activities began, Talk about plants, discuss the activities carried out, on core activities: plagiarizing and arranging leaves from small to large, closing activities: Q\&A about the activities carried out, short stories about messages, information on tomorrow's activities, singing, praying, greetings, home. The Daily Learning Implementation Plan compiled looks implicitly at the methods used, such as storytelling methods, singing methods, demonstrations, questioning, discussion, conversing and assigning tasks.

Based on the data processed and analyzed is qualitative data obtained through the triangulation process, namely observation of children's activities, interviews with teachers, and documentation analyzing the Daily Learning Implementation Plan, the results of the study show that the methods used in instilling Pancasila values in early childhood are aimed 
at students to achieve the following awareness: 1) Trust and taqwa to God Almighty; 2) manners and humane attitudes; 3 ) love for the nation and the homeland; 4) foster a democratic spirit; and 5) a sense of justice, honesty, truth and helping others in KB Anugrah, KB Nifaeri, KB Samadaya, Paud Umbu, Anugrah Sendoro Private Kindergarten, Epiphania Christian Private Kindergarten, including methods of playing, storytelling methods, method of demonstration, method of conversation, role-playing methods, habituation methods, methods of singing, method of travel.

Through interviews with informants, all agreed that by playing, children have also indirectly embedded Pancasila values, such as togetherness/unity, justice, honesty, truth and helping others. The value can in the way they play. If another friend falls and gets hurt, they will help him. Another example that is done is children play together without distinction in terms of ethnicity, religion, race, and inter-religion, social and economic background, finished playing together to organize and tidy up and save the game used again as for examples of play that is often carried out to instil the value of Pancasila above, among others, composing blocks or puzzles, finding friends, looking for a partner, small football, throwing a ball, jumping rope, and other traditional games. Teachers themselves make game tools, and some are already available in schools.

The method of storytelling is the delivery or presentation of learning materials orally in the form of stories from teacher to child. From the interviews with teachers, the form of stories that are often used is related to moral values, society, the value of heroism (Nationalism). To explain the story so that it can be understood, the teacher's child uses media, especially image media such as images of heroes, images of state emblems, images of houses and traditional clothes, images of people in ablution and prayer, images of animals (Stories of Deer and Crocodiles) and others. To reduce obstacles in storytelling, such as the lack of story themes, teachers use storybooks that are pretty available in schools.

The demonstration method is to show, work, and explain things. From the interview results, the method of demonstration conducted, among others, is to show the ordinance of ablution and movements in prayer-demonstrations about how to cross parents in the street. From the observations, it appears that children are practising how to take wudhu water and pray in the mosque. The activities are carried out in the mosque because all kindergarten schools that are research sites are very close to the mosque. Other observations of children's activities at the ceremony every Monday showed the child's respect when the national anthem was sung and raised. Another activity is seen when children queue in line and queue to wash their hands in the classroom.

The method of conversing in the form of conversation or questioning activities between the child with the teacher or between the child with the child. Based on interviews with teachers, conversation techniques are often carried out in the form of free conversations, conversations according to themes, and conversing based on serial pictures. Free conversations that teachers often do are asking about children's experiences at home, in the garden, on the beach, and others. Conversing according to the theme is to follow the themes arranged by the school. From documentation data and interviews with teachers, these themes include the theme of the semester I (one) consisting of self, environment, needs, animals, and plants, while the theme of semester II (two) consists of recreation/transportation, work, communication tools, water, air, fire, my homeland, and the universe. The teachers also explained that the approach of learning in kindergarten uses "thematic" so that the cultivation of Pancasila values is not only on specific themes that are directly related but all themes are always teachers integrating it with Pancasila values such as godly values, human values, unity values, deliberation/democracy values, and the value of justice. While conversing based on series images that use series images as speakers, examples of series images carried out by teachers and children include series images of ablution ordinances, prayers, and series images in storybooks that are pretty available in schools. 
The role-playing method provides experience to children through role-playing; namely, children are asked to play a specific role in a game. From his interviews with teachers, role-playing methods implemented include playing the sale and purchase of vegetables, playing to help the sick (Doctor), crossing over older people (Police), playing loving family, and the role of prayer imams and others.

Habituation methods are activities carried out regularly and continuously to train children to have certain habits that are generally related to the development of children's personalities, such as emotions, discipline, ethics, independence, self-adjustment, community life. Instilling religious values is done by teaching children before learning in the habit of praying first. In addition, when eating and little by little can teach short letters that are easily memorized by children (if Islam). The love of the homeland is instilled in children from an early age through, for example, with a simple ceremony every Monday with the red and white flag salute, singing the song Indonesia Raya and saying Pancasila. Another activity is to commemorate the national holiday with competition activities or cultural stages, introducing various cultures of the nation, such as regional dance and regional songs. Another thing that is accustomed to children by maintaining a clean environment by throwing garbage in the trash.

The singing method is an early childhood learning method that uses singing media to teach children's learning. The songs often sung are spiritual, national songs, and regional songs. To help teachers process the singing ability of their students, electronic media are used downloaded from youtube.

Travel is one method of teaching activities in kindergarten by observing the world by the reality that exists directly, including humans, animals, plants, and other objects. Based on the results of interviews with teachers, this method of travel will be carried out at the end of the semester, which they refer to as the peak of the "theme." Moreover, the place is only around the child's environment, namely tours to the beach; this is done to avoid the spread of Covid 19. Children's activities in this tourist spot, teachers explain the vastness of the sea and the beauty of the beach as a creation of God, other things children can see forms of cooperation, please help fishers such as pulling fishing nets, lowering and raising the boat is done together and in terms of humanity and justice where the fishermen's catch is partly distributed to people who have helped as well as the gratitude of fishermen for the blessings of god-given sustenance. Another thing taught by teachers is the love of the environment; namely, children are told to clean up the garbage on the beach.

\section{Discussion}

In reality, all children love to play. Games are suitable for educating children, but they must be given educational content so that children can learn. By playing, children have also indirectly embedded Pancasila values, such as togetherness/unity, please-help. Social skills at the time of play, children interact with other children. These interactions teach children to respond, give and receive, reject or agree with other children's ideas and behaviors. It will gradually reduce the egocentric feeling of the child and develop his social abilities. Playing children indirectly has embedded Pancasila values such as justice, honesty, truth, and helping others. These values can be seen in the way they play (Bakhtiyar, 2019; Fatmawati et al., 2018). If another friend falls and gets hurt, they will help him.

Instilling religious values can be done by teaching children before learning in the habit of praying first. In addition, when eating and little by little can teach short letters that are easily memorized by children (if Islam). A teacher can also invite his students to commemorate religious holidays, fasting in children, even if only half a day.

The love of the homeland can be instilled in children from an early age through, for example, with a simple ceremony every Monday with the red and white flag salute, singing the song Indonesia Raya and saying Pancasila. Although the song is still tricky and lengthy, the child will memorize and understand the song's content by getting used to singing it every 
Monday. Another activity is to commemorate the national holiday with competition activities or cultural stages, introducing various cultures of the nation simply by showing miniature temples and instilling the value of Pancasila in children from an early age. No less interesting is the story, pictures of houses and traditional clothes, wearing traditional clothes on Kartini day, as well as visiting the nearest museum, getting to know the heroes through storytelling. In addition to the above, the values of Pancasila can also be instilled by: 1) Circle the Calendar, Learning is connected to calendar and time. The teacher marks the dates on the calendar related to various activities, such as Kartini Day, Independence Day, and Heroes' Day. It can also be related to religious activities, such as Christmas, Ramadan, Eid al-Fitr, Nyepi, and Vesak; 2. Visit/Travel, Generally, children are happy to see firsthand the various realities in the community through visits. Various visiting activities such as the struggling Museum, aerospace museum, library, police can inspire to develop their ideas (Amu \& Tampi, 2021; Bakhtiyar, 2019; Fatmawati et al., 2018; Sukmalia et al., 2021). In kindergarten education, for the benefit of development and moral learning, it can be done by storytelling, tourist work, singing, saying rhymes, etc. The story, pictures of houses and traditional clothes, wearing traditional clothes on Kartini day, and visiting the nearest Museum, get to know the heroes through storytelling. Travel indirectly can foster an attitude to appreciate. For example, travel to historical relics such as museums. Children can appreciate that the Museum is a place to learn through relics from the ancients so that in their hearts will appear a feeling to maintain and preserve it. The purpose of forming behavior and morals in children from an early age is to prepare children as early as possible in instilling the Value of Pancasila in Children From an Early Age (Febriyanti \& Dewi, 2021; Suryatni, 2017).

\section{CONCLUSION}

The value of Pancasila is very appropriate if it is instilled in children from a very young age. It is so that after they grow up, they will be accustomed to actions and behaviour that follow the values of Pancasila. In addition to parental guidance, early childhood also needs to be given education in schools to plant Pancasila values more deeply embedded in their souls. Instilling morals in children early is also an essential need. Thus, children can develop attitudes and behaviours based on the values of Pancasila so that they grow into children who have a noble character who have morals according to the expectations of the nation.

\section{ACKNOWLEDGMENT}

Thank you to the Managers and Kindergarten Teachers in West Gunungsitoli District for their support and participation in implementing this research.

\section{BIBLIOGRAPHY}

Amu, S., \& Tampi, F. L. (2021). Metode Penanaman Nilai-Nilai Pancasila Pada Anak Usia Dini di Taman Kanak-Kanak Kecamatan Pinolosian Kabupaten Bolaang Mongondow Selatan. KIDSPEDIA: Jurnal Pendidikan Anak Usia Dini, 2(1), 1-10. https:// doi.org/10.30631/smartkids.v2i2.65

Angraini, R., Tiara, M., Waldi, A., \& N, N. (2019). Penggunaan Media Gambar dalam Menanamkan Nilai-nilai Pancasila pada Anak Usia Dini. JED (Jurnal Etika Demokrasi), 4(1). https:// doi.org/10.26618/jed.v4i1.2084

Ariani, F. (2019). Orang Tua Sebagai Penanam Nilai Pancasila Untuk Anak Usia Dini Di Era Digital. Journal of Early Childhood Education (JECE), 1(2), 60-68. https:// doi.org/10.15408/jece.v1i2.12515

Bakhtiyar, . (2019). Internalisasi Nilai-Nilai Moralitas Dan Kesantunan Pada Anak Usia Dini. Journal of Urban Sociology, 1(1), 70. https:// doi.org/10.30742/jus.v1i1.565 
DOI: 10.31004/obsesi.v6i4.2247

Dhiu, K., \& Laksana, D. N. L. (2021). The Aspects Of Child Development On Early Childhood Education Curriculum. Journal of Education Technology, 5(1), 1. https:// doi.org/10.23887/jet.v5i1.30764

Fatmawati, E., Huzaimah, E., \& Nafiqoh, H. (2018). Mengembangkan Nilai Moral Dan Disiplin Aud Melalui Metode Bercerita. CERIA (Cerdas Energik Responsif Inovatif Adaptif), 1(2), 41. https://doi.org/10.22460/ceria.v1i2.p41-46

Febriyanti, N., \& Dewi, D. A. (2021). Pengembangan Nilai Moral Peserta Didik Dalam Pembelajaran Pendidikan Kewarganegaraan. Jurnal Kewarganegaraan, 5(2), 476-482.

Fitriyani, F., Afifah, N. A., \& ... (2021). Perwujudan Nilai Pancasila Dalam Membentuk Moral Anak Di Era Digital: Study Literature. Jurnal Dikoda, 2(2), 16-23. https://jurnal.pelitabangsa.ac.id/index.php/JPGSD/article/view/901

Gunadi, R. A. A. (2013). Membentuk karakter melalui pendidikan moral pada anak usia dini di sekolah Raudhatul Athfal (R.A) Habibillah. Jurnal Ilmiah WIDYA, 1(2), 85-91. https://e-journal.jurwidyakop3.com/index.php/jurnal-ilmiah/article/view/133

Harefa, A. (2019). The Effect of Morality Development through Public Education on Junior High School Student Ethics ( Case Study in North Gunungsitoli - Indonesia ). Journal of Advances in Education and Philosophy, 2665(2), 58-61. https://doi.org/10.21276/jaep.2019.3.2.3

Harefa, A. (2021). Pengaruh pemahaman mahasiswa PPKn tentang seni budaya terhadap inventarisasi budaya masyarakat Nias Tahun Akademik 2020/2021. KAUKO: Jurnal Pancasila Dan Kewarganegaraan, 1(1), 18-28.

Hildebrandt, C., \& Zan, B. (2015). Pendekatan Konstruktivis pada Pendidikan Moral Anak Usia Dini. In Handbook Pendidikan Moral dan Karakter (pp. 511-536). Nusa Media.

Jamiatul, J., Maghfiroh, M., \& Astuti, R. (2020). Pola Asuh Orang Tua danPerkembangan Moral Anak Usia Dini (Studi Kasus di TK Al-Ghazali Jl. Raya Nyalaran Kelurahan Kolpajung Kecamatan Pamekasan Kabupaten Pamekasan). Kiddo: Jurnal Pendidikan Islam Anak Usia Dini, 1(1), 1-9. https:// doi.org/10.19105/kiddo.v1i1.2973

Khaironi, M. (2017). Pendidikan Moral Pada Anak Usia Dini. Jurnal Golden Age, 1(01), 1. https://doi.org/10.29408/goldenage.v1i01.479 https://doi.org/10.29408/goldenage.v1i01.479

Kusumawati, I., \& Zuchdi, D. (2019). Pendidikan Moral Anak Usia Dini Melalui Pendekatan

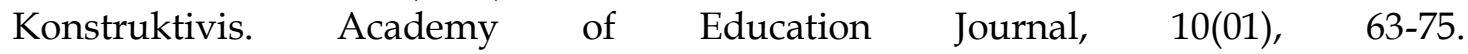
https://doi.org/10.47200/aoej.v10i01.272

Lancaster, D. (2001). A problem solving environment based on CORBA. Scientific Programming, 9(4), 233-242. https:// doi.org/10.1155/2001/645763

Lingkungan, K. A., Seribu, I. T., \& Binjai, K. (2021). Penguatan pendidikan pancasila dan kewarganegaraan sejak usia dini di kalangan anak-anak lingkungan i tanah seribu kota binjai. JKPM: Jurnal Pengabdian Kepada Masyarakat, 1(1), 21-31.

Muliana, S., Fakhriah, \& Rosmiati. (2017). Peran Orant Tua Dalam Mengembangkan NilaiNilai Moral Anak Usia Dini Di Kabupaten Bener Meriah. Jurnal Ilmiah Mahasiswa Pendidikan Guru Anak Usia Dini, 2(2), 77-84.

Pratama, N. Y. P., \& Dewi, D. A. (2021). Implementasi Nilai-Nilai Pancasila dalam Membentuk Moral Bangsa yang Terkikis Akibat Benturan Globalisasi. Jurnal Pendidikan Tambusai, 5(1), 962-968. https://www.jptam.org/index.php/jptam/article/view/1046

Rusdiyani, E. (2015). Pembentukan Karakter dan Moralitas bagi Generasi Muda yang Berpedoman pada Nilai-nilai Pancasila serta Kearifan Lokal. Seminar Nasional, 33-46.

Ruslan, R. (2020). Penanaman Pendidikan Moralitas dan Nilai Pancasila Anak Usia Dini dalam Perkembangan IPTEK. Abdimas: Papua Journal of Community Service, 2(1), 11. https://doi.org/10.33506/pjcs.v2i1.807

Sriwahyuni, E., Asvio, N., \& Nofialdi, N. (2017). Metode Pembelajaran Yang Digunakan PAUD (Pendidikan Anak Usia Dini) Permata Bunda. ThufuLA: Jurnal Inovasi 
$\begin{array}{lllll}\text { Pendidikan Guru } & \text { Raudhatul }\end{array}$ https:// doi.org/10.21043/thufula.v4i1.2010

Sukmalia, M., Riadi, F. S., Dewi, D. A., \& Furnamasari, Y. F. (2021). Urgensi Penanaman Nilainilai Ideologi Pancasila Pada anak Sekolah Dasar Di Masa Pandemi Covid-19. Jurnal Ilmiah Profesi Pendidikan, 6(3), $336 \quad$ - 341. https:// doi.org/https:// doi.org/10.29303/jipp.v6i3.239

Sulastri, N. M. (2021). Identifikasi Metode Pembelajaran Yang Diterapkan Guru Paud Dalam Mengembangkan Kemampuan Kognitif Anak Usia 5-6 Tahun. Journal Scientific of Mandalika (JSM), 2(11), 103-107. http://ojs.cahayamandalika.com/index.php/jomla/issue/archive

Suryadi, B. (2015). Pendidikan Karakter : Solusi Mengatasi Krisis Moral Bangsa. NIZHAM, 4(2), 288-306.

Suryatni, L. (2017). Pendidikan Karakter Berdasarkan Pengamalan Nilai-Nilai Moral Pancasila Sebagai Jati Diri Bangsa Indonesia. Jurnal Ilmiah Hukum Dirgantara, 7(2), 17-29. https://doi.org/10.35968/jh.v7i2.131

Yenni, S. F. (2017). Penggunaan Model Pembelajaran Pendidikan Karakter Abad 21 pada Anak Usia Dini. Jurnal Obsesi: Jurnal Pendidikan Anak Usia Dini, 1(1), 52-61. https:// doi.org/10.31004/obsesi.v1i1.31

Zagoto, M. M., \& Dakhi, O. (2018). Pengembangan Perangkat Pembelajaran Matematika Peminatan Berbasis Pendekatan Saintifik Untuk Siswa Kelas Xi Sekolah Menengah Atas. Jurnal Review Pendidikan Dan Pengajaran, 1(1), 157-170. https:// doi.org/10.31004/jrpp.v1i1.884

Zagoto, M. M., Yarni, N., \& Dakhi, O. (2019). Perbedaan Individu Dari Gaya Belajarnya Serta Implikasinya Dalam Pembelajaran. Jurnal Review Pendidikan Dan Pengajaran, 2(2), 259-265. https://doi.org/10.31004/jrpp.v2i2.481 